\title{
Association between an Alul Polymorphism in the Calcitonin Receptor Gene and Quantitative Ultrasound Parameters in Korean Men
}

\author{
Byung Yong Kang ${ }^{a}$ Ji Young Kim ${ }^{b}$ Kang Oh Lee \\ ${ }^{a}$ Research Institute for Life Science and ${ }^{b}$ Department of Life Science, Sahmyook University, Seoul, \\ Republic of Korea
}

\section{Key Words}

Bone mineral density · Calcaneus $\cdot$ Calcitonin receptor gene $\cdot$ Vegetarian diet

\begin{abstract}
Objective: The purpose of this study was to investigate the association between an Alul RFLP of the calcitonin receptor (CTR) gene and quantitative ultrasound (QUS) parameters in Korean men, and the interaction with nutrition as a lifestyle factor. Materials and Methods: Broadband ultrasound attenuation, speed of sound and stiffness index of the calcaneus were measured using an ultrasound bone densitometer in 201 Korean men (mean age \pm SD: $51.6 \pm 11.7$ years). The PCR-RFLP method was used to analyze an Alul polymorphism in the CTR gene. Results: In all subjects, the distribution of CC, CT and TT genotypes occurred with frequencies of $87.1,12.4$ and $0.5 \%$, respectively. When stratified by omnivore and vegetarian groups, there was a significant association between an Alul polymorphism in the CTR gene and QUS parameters such as speed of sound and stiffness index in only vegetarian subjects. Conclusion: Our data suggest that the Alul polymorphism of the CTR gene can be useful as a genetic marker in the interindividual susceptibility of QUS parameters by the interaction with nutritional status as a lifestyle factor.

Copyright $\odot 2007$ S. Karger AG, Basel
\end{abstract}

\section{Introduction}

Osteoporosis is recognized as one of the most important disorders of aging and defined as a disease characterized by low bone mineral density (BMD) and microarchitectural deterioration of bone. Many environmental factors, including diet and exercise, have been implicated in disease pathogenesis, but genetic factors are now recognized as one of the most important determinants of BMD [1-3].

Calcitonin (CT) is a key polypeptide hormone that plays an important role in bone and calcium homeostasis. CT is expressed and secreted in parafollicular cells of the thyroid gland, inhibits bone resorption by osteoclast and stimulates urinary calcium excretion through the mediation by specific receptors [4]. The human CT receptor (CTR) gene was cloned from ovarian carcinoma cell line and recognized to be a prototypic member of a distinct family of $G$ protein-coupled receptors with seven transmembrane domains [5]. Nakamura et al. [6] reported an AluI polymorphism characterized by a single nucleotide transition (C to T polymorphism) at position 1377 of human CTR cDNA in the Japanese population. Subsequently, this polymorphism has been used as genetic marker for several clinical association studies such as osteoporosis [7] and breast cancer [8].

\section{KARGER}

Fax +4161306 1234

E-Mail karger@karger.ch

www.karger.com
(C) 2007 S. Karger AG, Basel

1011-7571/07/0165-0389\$23.50/0

Accessible online at:

www.karger.com/mpp
Prof. Kang Oh Lee

Department of Life Science, Sahmyook University

Seoul 139-742 (Republic of Korea)

Tel. +82 23399 1718, Fax +82 233991729

E-Mail k5lee@syu.ac.kr 
Table 1. Clinical characteristics of omnivores and vegetarians

\begin{tabular}{lcc}
\hline Variables & $\begin{array}{l}\text { Omnivores } \\
(\mathrm{n}=136)\end{array}$ & $\begin{array}{l}\text { Vegetarians } \\
(\mathrm{n}=64)\end{array}$ \\
\hline Age, years & $51.6 \pm 12.2$ & $50.8 \pm 11.1$ \\
Height, $\mathrm{cm}^{2 *}$ & $168.8 \pm 5.9$ & $167.0 \pm 5.6$ \\
Weight, $\mathrm{kg}$ & $64.1 \pm 8.4$ & $62.2 \pm 7.8$ \\
BMI & $22.4 \pm 2.4$ & $22.2 \pm 2.8$ \\
BUA, dB/MHz & $62.2 \pm 5.0$ & $62.7 \pm 5.2$ \\
BUA T score & $-1.4 \pm 0.9$ & $-1.4 \pm 0.9$ \\
SOS, m/s & $1,650.8 \pm 43.4$ & $1,649.2 \pm 42.4$ \\
Stiffness index & $83.9 \pm 13.0$ & $83.8 \pm 12.7$ \\
Calcium intake, mg/day & $564.6 \pm 356.9$ & $487.7 \pm 322.7$ \\
\hline
\end{tabular}

${ }^{*} \mathrm{p}<0.05$. These parameters were not measured from an individual. Data are expressed as mean $\pm \mathrm{SD}$.

The BMD in vegetarians is usually lower than in omnivores because of the difference in dietary calorie, protein and fat intake between the two groups [9]. There have been few reports [10-12] about the genetic factor in the interindividual difference of BMD according to nutritional condition. Therefore, the purpose of this study was to determine the relationship between the CTR AluI polymorphism as a genetic factor and bone ultrasound properties in both Korean vegetarian and omnivore groups.

\section{Materials and Methods}

\section{Study Subjects}

A total of 201 unrelated individuals with average age of $51.6 \pm$ 11.7 years were selected from Department of Health and Social Welfare, Sahmyook Nursing and Health College, Seoul, Korea. The omnivores (136 subjects, average age of $51.6 \pm 12.2$ years) consumed unlimited food, while the vegetarian (65 subjects, average age of $50.8 \pm 11.1$ years) have been consuming only vegetables for at least 20 years. Subjects with a known history of diabetes, hypothyroidism, hyperparathyroidism, chronic retinopathy, rheumatoid arthritis, and stroke were excluded because these diseases can affect the bone ultrasound properties. Subjects who had received drug treatment in the form of steroids, diuretics, antispasmodics, bisphosphonates, vitamin D or calcium supplements were also excluded from the study. Informed consent was obtained from each individual.

\section{Measurement of Bone Parameters}

Quantitative ultrasound (QUS) measurement of the calcaneum of the left foot was measured in the 201 subjects using an ultrasound machine (Pegasus CDR NO-CE0459, France). For measurement of stiffness index, broadband ultrasound attenuation (BUA) and speed of sound (SOS; $\mathrm{m} / \mathrm{s}$ ) were measured. The stiff- ness index values were estimated with the following formula: $0.67 \cdot \mathrm{BUA}+0.28 \cdot \mathrm{SOS}-420$ [13]. The coefficient of variation for BUA and SOS measurements was 8.2 and $2.6 \%$, respectively. For calcium intake assessment, we used a questionnaire previously reported in studies of osteoporosis in China [14].

\section{Genotype Analysis of CTR AluI RFLP}

Genomic DNA was prepared from buffy coats from blood $(5 \mathrm{ml})$ and then was screened for the CTR AluI polymorphism using PCR reaction, followed by AluI digestion, according to a previously published protocol [7].

\section{Statistical Analysis}

All statistical analyses were performed using SPSS for Windows v11.0 (SPSS, Inc., Chicago, Ill., USA). The subjects were categorized into three groups depending on each genotype. Significant differences in age, BMI, BUA, BUA T score, SOS, stiffness index, and calcium intake between the groups were examined using unpaired Student's $t$ test. The gene counting method estimated allele frequencies. Deviation in genotype distribution from that expected for Hardy-Weinberg equilibrium was estimated by $\chi^{2}$ fitness test. The significance of differences in allele frequencies between groups was also estimated by $\chi^{2}$ independence test. A parametric one-way ANOVA was performed to compare the variables across the genotypes. To detect the interaction between lifestyle factor and genetic factor for the determination of the QUS parameters, a two-way ANOVA was performed.

\section{Results}

The clinical parameters of the study subjects are listed in table 1. Compared to vegetarians, the height of omnivores was significantly greater than that of vegetarians, but the differences in the other parameters were not statistically significant between the two groups. However, vegetarians tended to have a lower calcium intake than omnivores ( $487.7 \pm 322.7$ vs. $564.6 \pm 356.9 \mathrm{mg} /$ day).

The genotype and allele frequencies of the AluI RFLP in the CTR gene are shown in table 2. The observed genotype distribution of the AluI RFLP did not deviate from the Hardy-Weinberg equilibrium. The observed genotype frequencies of CC, CT, and TT were 87.7, 12.3, and $0.0 \%$ in vegetarians, and $86.8,12.5$, and $0.7 \%$ in omnivores, respectively. The frequencies of the $\mathrm{C}$ and $\mathrm{T}$ alleles were 0.933 and 0.067 , respectively. There were no statistically significant differences between omnivores and vegetarians in allele and genotype distribution.

The comparison of bone phenotypes across the AluI RFLP in the CTR gene is given in table 3 . There were no significant differences between any QUS parameter studied and genotype in total and omnivore subjects. There were significant differences between QUS parameters such as SOS or stiffness index and genotype in only veg- 
Table 2. Genotype and allele frequencies of AluI RFLP in the CTR gene in vegetarians and omnivores

\begin{tabular}{|c|c|c|c|c|c|}
\hline & \multicolumn{3}{|l|}{ Genotype } & \multicolumn{2}{|l|}{ Allele } \\
\hline & CC & CT & TT & $\mathrm{C}$ & $\mathrm{T}$ \\
\hline Vegetarian & $57(87.7)$ & $8(12.3)$ & $0(0.0)$ & $122(93.8)$ & $8(6.2)$ \\
\hline Omnivore & $118(86.8)$ & $17(12.5)$ & $1(0.7)$ & $253(93.0)$ & $19(7.0)$ \\
\hline Total & $175(87.1)$ & $25(12.4)$ & $1(0.5)$ & $375(93.3)$ & $27(6.7)$ \\
\hline$\chi^{2}$ & \multicolumn{3}{|c|}{0.4836} & \multicolumn{2}{|c|}{0.0097} \\
\hline d.f. & \multicolumn{3}{|c|}{2} & \multicolumn{2}{|c|}{1} \\
\hline Probability & \multicolumn{3}{|c|}{0.7852} & \multicolumn{2}{|c|}{0.9215} \\
\hline
\end{tabular}

Observed genotype distribution was in Hardy-Weinberg equilibrium in all groups $(\mathrm{p}>0.05)$. Figures in parentheses are percentages.

Table 3. Characteristics of study subjects according to the AluI RFLP in the CTR gene

\begin{tabular}{|c|c|c|c|c|c|c|}
\hline Parameters & \multicolumn{2}{|l|}{ Omnivore } & \multicolumn{2}{|l|}{ Vegetarian } & \multicolumn{2}{|l|}{ All subjects } \\
\hline Age, years & $52.3 \pm 12.2$ & $50.2 \pm 11.3$ & $51.5 \pm 11.1$ & $44.9 \pm 8.8$ & $52.0 \pm 11.8$ & $48.6 \pm 10.7$ \\
\hline BMI & $22.3 \pm 2.3$ & $23.4 \pm 2.7$ & $22.2 \pm 2.8$ & $23.0 \pm 2.6$ & $22.3 \pm 2.5$ & $23.3 \pm 2.6$ \\
\hline $\mathrm{BUA}, \mathrm{dB} / \mathrm{MHz}$ & $62.5 \pm 5.0$ & $60.8 \pm 3.9$ & $62.4 \pm 5.3$ & $63.0 \pm 5.0$ & $62.5 \pm 5.1$ & $61.4 \pm 4.3$ \\
\hline Stiffness index ${ }^{*}$ & $84.8 \pm 12.7$ & $79.1 \pm 11.8$ & $82.7 \pm 12.3$ & $92.3 \pm 11.2$ & $84.1 \pm 12.6$ & $83.2 \pm 13.0$ \\
\hline Calcium intake, mg/day & $563.7 \pm 363.1$ & $561.6 \pm 304.4$ & $459.6 \pm 306.7$ & $639.9 \pm 384.1$ & $529.8 \pm 348.3$ & $585.7 \pm 325.1$ \\
\hline
\end{tabular}

${ }^{*} \mathrm{p}<0.05$.

etarian subjects $(\mathrm{p}<0.05)$. A two-way ANOVA test to analyze the interaction effect between genotype factor (CC, CT or TT) and lifestyle factor (omnivore or vegetarian) for the determination of QUS parameters revealed the significant interaction effect between these factors (for SOS index, F value for genotype factor $=0.822, \mathrm{p}=$ 0.441 ; F value for lifestyle factor $=3.567, \mathrm{p}=0.060$; $\mathrm{F}$ value for the interaction between two factors $=6.983, \mathrm{p}=$ 0.009; for stiffness index, $\mathrm{F}$ value for genotype factor $=$ $0.595, \mathrm{p}=0.553 ; \mathrm{F}$ value for lifestyle factor $=4.224, \mathrm{p}=$ 0.041; $\mathrm{F}$ value for the interaction between two factors = $7.477, \mathrm{p}=0.007)$. It is likely that the AluI polymorphism significantly contributes to the interindividual difference in QUS parameters through the interaction with lifestyle factors such as vegetarian diet in Korean men.

\section{Discussion}

In a recent study, the $\mathrm{BMD}$ of elderly Chinese vegetarian women was reported to be consistently lower in the vegetarians than omnivorous controls [9]. The difference in BMD between vegetarians and omnivores could be due to the difference in dietary intakes. Vegetarians had a higher carbohydrate, lower energy, fat and protein intake and a low calcium uptake than omnivores. Because protein supplementation had been shown to prevent bone loss in osteoporosis [15], the vegetarian diet could lead to low BMD. Low dietary calcium intake has been shown to be associated with increased risk of both hip and vertebral fractures $[14,16]$.

In the present study, we hypothesized that the bone ultrasound properties may be influenced by the interaction between the AluI polymorphism of the CTR gene as a genetic factor and nutrition status as a lifestyle factor. 
The $\mathrm{T}$ allele of the AluI gene polymorphism is significantly associated with SOS and stiffness index among bone ultrasound properties measured in Korean vegetarian subjects. Thus, the present data supported the protective effect of this allele on the risk factor of osteoporosis according to nutritional condition. There are many reports on the association between this polymorphism and $\mathrm{BMD}$ or osteoporosis in mainly postmenopausal women with inconsistent results [3, 7, 17-23]. Because this polymorphism is located within the fourth intracellular domain of CTR [6], and plays an important role in the binding of CT, the significant association between this polymorphism and some bone phenotypes in our study may reflect the functional role such as ligand binding activity. Also, we could not exclude the possibility that this association may be due to linkage disequilibrium between the causative allele and this polymorphism in our study subjects. However, this association was not maintained in the omnivore group. The reason for this is unclear, but the effect of this polymorphism may be masked in the omnivore group because the latter maintained relatively high bone ultrasound properties through higher calcium intake than the vegetarian group, although this was not statistically significant. In summary, it is likely that the AluI polymorphism of the CTR gene might be one of genetic components associated with QUS parameters through the interaction with lifestyle factor such as vegetarian diet in Korean men. Nevertheless, due to the modest sample size, our results must be interpreted with caution, and further studies using larger sample size and various ethnic groups will be needed to clarify the relationship between this polymorphism and these bone parameters.

\section{Conclusion}

The results from our study supported the hypothesis that the AluI polymorphism of the CTR gene becomes effective in the interindividual difference in QUS parameters such as SOS and stiffness index through the interaction with lifestyle factors such as vegetarian diet.

\section{Acknowledgement}

We wish to acknowledge Dr. So Yeon Kim, Department of Health and Social Welfare, Sahmyook Nursing and Health College, for providing samples.

\section{References}

$>1$ Pocock NA, Eisman JA, Hopper JL, Yeates MG, Sambrook PN, Eberl S: Genetic determinants of bone mass in adults: a twin study. J Clin Invest 1994;80:706-710.

$\checkmark 2$ Seeman E, Hopper JL, Bach LA, Cooper ME, Parkinson E, McKay J, Jerums G: Reduced bone mass in daughters of women with osteoporosis. N Engl J Med 1994;320:554558.

$>3$ Braga V, Mottes M, Mirandola S, Lisi V, Malerba G, Sartori L, Bianchi G, Gratti D, Rossini M, Bianchini D, Adami S: Association of CTR and COLIA1 alleles with BMD values in peri-and postmenopausal women. Calcif Tissue Int 2000;67:361-366.

4 Nicholson GC, Moseley JM, Sexton PM, Mendelsohn FA, Martin TJ: Abundants calcitonin receptors in isolated rat osteoclasts: biochemical and autoradiographic characterization. J Clin Invest 1986;78:355-360.

$>5$ Gorn AH, Lin HY, Yamin M, Auron PE, Flannery MS, Tapp DR, Manning CA, Lodish HF, Krane SM, Goldring SR: Cloning, characterization, and expression of a human calcitonin receptor from an ovarian carcinoma cell line. J Clin Invest 1992;90:176-1735.
-6 Nakamura M, Zhang Z, Shan L, Hisa T, Sasaki M, Tsukino R, Yokoi T, Kaname A, Kakudo K: Allelic variants of human calcitonin receptor in the Japanese population. Hum Genet 1997;99:38-41.

$\checkmark 7$ Tsai FJ, Chen WC, Chen HY, Tsai CH: The AluI calcitonin receptor gene polymorphism (TT) is associated with low bone mineral density and susceptibility to osteoporosis in postmenopausal women. Gynecol Obstet Invest 2003;55:82-87.

-8 Nakamura M, Jing X, Zhang Z, Yasuoka H, Nakamura Y, Yokoi T, Oura S, Sakurai T, Kakudo K: Genetic variants of calcitonin receptor and breast cancer in Japanese. Breast 1999;8:104-106.

$\checkmark 9$ Lau EMC, Kwok T, Ho SC: Bone mineral density in Chinese elderly female vegetarians, vegans, lacto-vegetarians and omnivores. Eur J Clin Nutr 1998;52:60-64.

10 Ferrari SL, Karasik D, Liu J, Karamohamed S, Herbert AG, Cupples LA, Kiel DP: Interactions of interleukin- 6 promoter polymorphisms with dietary and lifestyle factors and their association with bone mass in men and women from the Framingham Osteoporosis study. J Bone Miner Res 2004;19:552-559.
11 Otsuki T, Sakaguchi H, Hatta E, Hatayama T, Hatada S, Miura Y, Takata-Tomokuni A, Hyodoh F, Tomomitsu T, Fukunaga M, Katsuyama $\mathrm{H}$ : Effects of genetic and nutritional factors on bone mineral density in young adults. Int J Mol Med 2004;14:669-676.

12 Rapuri PB, Gallagher JC, Knezetic JA, Kinyamu HK, Ryschon KL: Association between vitamin $\mathrm{D}$ receptor polymorphisms and the rate of bone loss in elderly women-importance of adjusting for dietary and lifestyle factors. J Steroid Biochem Mol Biol 2004;8990:503-506

13 van Daele PL, Burger H, Algra D, Hofman A, Grobbee DE, Birkenhanger JC, Pols HA: Age-associated changes in ultrasound measurements of the calcaneus in men and women: the Rotterdam Study. J Bone Miner Res 1994;9:1751-1757.

14 Lau, E, Donnan S, Barker DJ, Cooper C: Physical activity and calcium intake in fracture of the proximal femur in Hong Kong. Bone Miner J 1988;297:1441-1443. 
15 Tkatch L, Rapin CH, Rizzori R, Slosman D, Nydegger V, Vasey H, Bonjour JP: Benefits of oral protein supplement in elderly patients with fracture of the proximal femur. J Am Coll Nutr 1992;11:519-525.

16 Chan HHL, Lau EMC, Woo J, Lin F, Sham A, Leung PC: Dietary calcium intake, physical activity and risk of vertebral fracture in Chinese. Osteoporosis Int 1996;6:228-232.

17 Bandres E, Pombo I, Gonzalez-Huarriz M, Rebollo A, Lopez G, Garcia-Foncillas J: Association between bone mineral density and polymorphisms of the VDR, Eralpha, COL1A1 and CTR genes in Spanish postmenopausal women. J Endocrinol Invest 2005;28:312-321.
18 Braga V, sangalli A, Malerba G, Mottes, Mirandola S, Gatti D, Rossini M, Zamboni M, Adami S: Relationship among VDR (BsmI and FokI), COL1A1, and CTR polymorphisms with bone mass, bone turnover markers, and sex hormones in men. Calcif Tissue Int 2002;70:457-462.

19 Kang HJ and Ahn GS: RFLP of the calcitonin receptor gene in the Korean population. Korean J Genet 2001;23:177-182

20 Jang DH, Hwang YC, Kang BY, Choi SS, Kang CY and Ha NJ: AluI RFLP analysis of the calcitonin receptor gene in the Korean athletic men. Yakhak Hoeji 2004;48:75-81.

21 Masi L, Becherini L, Gennari L, Colli E, Mansani R, Falchetti A, Cepollaro C, Gonnelli S, Tanini A, Brandi ML: Allelic variants of human calcitonin receptor: distribution and association with bone mass in postmenopausal Italian women. Biochem Biophys Res Commun 1998;245:622-626.
22 Taboulet J, Frenkian M, Frendo JL, Feingold N, Jullienne A, de Vernejoul MC: Calcitonin receptor polymorphism is associated with a decreased fracture risk in postmenopausal women. Hum Mol Genet 1998;7:2129-2133.

23 Zofkova I, Zajickova K, Hill M, Krepelova A: Does polymorphism C1377T of the calcitonin receptor gene determine bone mineral density in postmenopausal women? Exp Clin Endocrinol Diabetes 2003;111:447449 